\title{
GAMBLING REVENUES AND TAXES \\ IN THE FINANCIAL STATEMENTS OF EUROPEAN COMPANIES
}

\author{
Eva Karai ${ }^{1}$ \\ Maria Lakatos ${ }^{2}$ \\ Judit Nagy ${ }^{3}$ \\ Janos Erdei ${ }^{4}$
}

DOI: https://doi.org/10.31410/tmt.2019.63

\begin{abstract}
Not only the operating system but the accounting method is strongly regulated in gambling companies. The accounting and tax regulations that differ by countries influence the accounting practices and so the financial statements of the companies. Revenues are one of the main indicators of the financial performance of an entity. We studied the presentation form and content of European gambling revenues using the presented financial statements of gambling companies between 2004 and 2013. We examined whether the divergent recognition and measurement methods led to a material impact on the comparability of the financial statements. Our results show that the potentially high gambling tax rate and its different accounting practice can hamper the decision making of users of these financial statements and the reliability of revenue-based indicators both on company and industry level. If specific interpretation or guidance for the gambling sector existed, financial statements provided enhanced information.
\end{abstract}

Keywords: Gambling Revenue, Gambling Tax, Comparability of Financial Statements.

\section{INTRODUCTION}

$\mathrm{P}$ laying is not only part of human nature but one of the engines for human development (Brenner \& Brenner, 1990). Gaming was an integral part of human culture in some ancient states and was already present in early 2000 BC (Greenlees, 2008). Conquering the world gambling has been growing in popularity. For decades, the gambling industry has attracted crowds of people looking for comfortable relaxation, fun and even family program for holidays. While the wheel revolves under the crystal chandeliers at the poker table, the odds accumulate in the inner rooms as an inexhaustible source of income, as a private and public revenue alike.

The casino gambling industry has rocketed at an incredible race. While forty years ago, casinos operating only in 13 countries and recording for less than $\$ 2$ billion in annual revenues, but with a few decades later, casinos operating in more than 130 countries, multiplied their revenues exceeded $\$ 125$ billion. (Siu, 2007) In the background of the legalization of gambling stand the purpose of achieving economic benefits through job creation, investment stimulation, tourism development, and urban revitalization (Eadington, 2003; Alvarez-Martinez et al., 2016). The desire to increase public revenues played another significant role in the spread of legal gambling (e.g. Smith, 2000). Most of the research on the social and economic impacts of gambling dates back only to the early 1990s. The development of this literature was largely concomitant with the introduction and growth of the casino industry in the USA (Walker \& Sobel, 2016) and in Europe (Kingma, 2004).

Eötvös Loránd University, Hungary, 1053 Budapest, Egyetem tér 1-3

Eötvös Loránd University, Hungary, 1053 Budapest, Egyetem tér 1-3

Budapest University of Technology and Economics, Hungary, 1111 Budapest, Mủegyetem rkp.

Budapest University of Technology and Economics, Hungary, 1111 Budapest, Müegyetem rkp. 
Studies on European gaming industry mainly focused on social and health implications (i.e. Beco, 1996, Meyer et al., 2009, Demetrovics et al., 2011, Körmendi, 2011, Planzer et al., 2014), the role and effectiveness of gambling taxes (i.e. Paton et al., 2002, Philander, 2013), meanwhile other researchers analyzed the financial performance of European casinos compared with casinos in the USA or Macau (i.e. Gu, 2002, Gu \& Gao, 2006, Eadington, 2011).

While the corporate model became the normative organizational form of North America, particularly in Las Vegas, the European casinos were operated under strict state control in the form of monopolies (Thompson, 1998). At the end of the 20th century, they were mainly government-owned, and force table games at the low rate of promotion and advertisement. Gambling taxes were sometimes so high that the state can be regarded as the primary owner channelling the winning from the real and private ones $(\mathrm{Gu}, 2002)$. Nowadays there are a different kind of gambling operators present in Europe depending on the state regulation of gambling (Nikkinen, Egerer \& Marionneau, 2018)

The regulations of gambling show considerable differences also in the European Union (Forberger \& Bühriner, 2014). The EU regarded the gambling markets as a national competency, and it was not changed through the Services Directive 2006 which excluded from the scope of the Directive because of its specific nature (Kingma, 2008).

In today's world, dominated by the Internet, mobile applications and online games play an ever more significant role in the gaming sector, thereby helping to satisfy basic human needs (Demetrovics et al., 2011). Online gambling is legal in many countries and extends far across national borders. This activity is usually regulated separately from traditional (land-based) gambling activities, and regulations may either strengthen or weaken the development of online markets (European Casino Association, 2015). Some nations regulate the spread of online activity through very high taxes and the restriction of services (Finger, 2013).

The country-specific regulations by countries influence the accounting practices and the content of the disclosures in the financial statements. Of course, a company may operate in different countries, and regulations of these countries are generally different from each other. Thus, companies are also required to provide disclosures by geographical segment, and according to local regulations.

Our research focuses on the revenues of companies that operate in the same industry but under different accounting basis or accounting treatments.

Our study aims to examine whether the variations in the recognition and measurement of revenue and gambling tax might have a significant impact on the financial statements and the value of the sector's total revenue.

\section{ACCOUNTING FOR GAMBLING REVENUE AND TAX IN EUROPEAN COUNTRIES}

European gambling companies follow domestic accounting rules/standards or international financial reporting standards (IFRS) when they prepare financial statements. Ding and co-researchers (2007) revealed absence and divergence in recognition, measurement, and disclosure between domestic and international accounting standards: some rules are missing in the domestic accounting systems, and some rules differ from the applied ones in IFRS. These differences 
may arise from their accounting basis (Langmead \& Soroosh, 2009), whereas IFRS is a principles-based system, most domestic accounting regulations can be viewed as a rules-based system.

The direct and indirect presence of IFRS is very high in Europe. The European Union requires from the member states to present consolidated financial statements based on IFRS as adopted in the EU in case of companies whose securities are traded in a regulated market. Furthermore, the member states have the option to require or permit IFRS also for other companies. Despite the widespread use of IFRS, national traditions and practices, the language difficulties (Andor \& Rózsa, 2013, Rózsa, 2013) and the differences between stakeholder groups and between countries (Albu et al., 2013) hamper and slow down the voluntary implementation or convergence of national regulations with IFRS.

IFRS follows principles-based accounting, whereas most European countries have rules-based accounting systems. Researchers (i.e. Armstron et al., 2007; Barth et al., 2008; Rezaee et al., 2010) consider as a key benefit in IFRS the high-level accounting quality, the comparability through eliminating accounting alternatives, and the fair value accounting. However, the lack of balance sheet and income statement formats complicates the comparability of financial statements (Hoogendoorn, 2006). Langmead \& Soroosh (2009) highlight that IFRS generally formulates the standards without specific industry guidances and this flexibility can provide opportunities for different accounting treatments (Barth et al., 2008).

Ahmed, Neel, and Wang (2013) mentioned revenue recognition as an area where the lack of implementation guidance may result in different interpretations and implementations.

Revenue provides information about the realized gross earnings from companies' business activities, the size of a company; it is the basis for a large number of financial ratios in profitability analysis and the performance evaluation of the management of companies (Wagenhofer, 2014).

In the revenues of gambling companies are revenues from banked games (also called as gaming activities) and gaming-related activities. Playing banked games, both the entity and the customer have the chance to win or lose money or other items of economic value depending on the outcome of the game. By gaming-related activities, only the customer has the chance of winning or losing money; the gaming entity receives a fee for administrating the game. (AICPA, 2017)

The specific features in the gaming and gaming-related activities enable that revenues can be recognized and presented in the financial statements of gambling entities differently. It can be presented theoretically in three levels. The sales revenue can include the gross wager (the total amount of bets) and the revenues from gaming-related activities. The gross gaming revenue is the difference between the amounts received and the amounts paid back to the players as gaming wins. In the case of net gaming revenue, the gross gaming revenue is adjusted by incentives, changes in accrued jackpot liabilities, or gaming tax.

The presentation of gambling revenue depends on the accounting practice applied by the entity, and the accounting practice may differ not only on the country level but even on the company level because of lacking uniform guidance.

There is a close relationship between accounting for gaming revenues and gambling tax. Gambling markets are typically taxed differently than the other part of the economy and alter by 
countries (Philander et al., 2015). The gambling taxes cannot be defined as a unique income or sales tax. Because the industry itself falls under strict state-run regulation, even if the state itself runs gambling companies as an owner, the taxation as a legal, or at least not forbidden activity, reflects its ambiguous position among the other legal income-generating activities. A unique mixture of taxation forms exists due administrative constraints; several countries levy on the taxation of the gambling companies' fixed assets or a combination of a unit and ad valorem taxes (Benar \& Jenkins, 2008). Gandullia and Leporatti (2019) highlighted the need for harmonization rules of gambling taxes at European level.

In the gaming industry, three categories of tax levies exist the company income tax, the gambling tax - as an excise tax-, and personal income tax on winnings.

Regular and gambling companies also fall under the scope of company income tax, computed on their revenue mainly based on accounted profit, but the calculation of the tax base via deductions and tax rate are different (Karai et al., 2018).

Gambling, similar to the trading of tobacco or alcohol, reflects a particular objective to punish an activity characterized as socially irresponsible (Meich, 2008), so excise tax levied on activity. Personal income tax - which is mainly a tax determined in a percentage of the gross winnings- is not subject to our research.

Clotfelter (2005) incorporates the profit of government-run or government-sanctioned enterprises as an implicit tax because the net income of these companies is channelled to the state budget.

The accounting treatment of the gambling tax is different, even by IFRS companies. When gambling tax is considered a sales tax, it should be eliminated, deducted from revenue because revenue cannot contain items that are due to a third party. In other cases, a gaming tax may qualify as an expense. In this sense, users of financial statements can find two kinds of a statement concerning accounting gaming taxes.

\section{METHODOLOGY AND DATA}

Our research aims at investigating gambling companies in Europe for which non-consolidated financial accounts of entities were extracted from the Amadeus database, covering a period from 2004 to 2013. Our search request brought more than 19,000 results for companies operating in the gambling business from 41 European countries. This sample is believed to cover the essence of the European gambling market. Amadeus provided applicable data for all 19,000 companies regarding their size and region. For the revenue analysis, we excluded more than 8,400 companies for which data on operating revenue was not available in the period examined. Therefore, the scope of the analyses has been restricted to the dataset of 10,590 companies. Our data collection cannot be considered random, so statistically, the available sample cannot be representative either. Regarding its proportion and size, the sample itself is significant, which indicates that our assessments and conclusions can be considered well-founded.

Companies have been classified into four categories: small, medium, large, and very large. This classification is made according to the values of operating revenues and total assets and the number of employees. 
In an earlier stage of the research, we analysed the structure of of the European gambling industry. Central and Eastern Europe are characterized by mid-sized and smaller companies. Southern Europe is characterized by mid-sized and larger companies, where more than half of the online companies we examined are situated. Western and Northern regions are characterized by large and very large companies, where the other half of the online companies we examined may be found (Karai, Nagy, Erdei \& Lakatos, 2018).

The operating revenue also shows significant differences between countries in the course of descriptive statistic processing; at the same time, the market seemed to be strongly concentrated in terms of the operating revenue. To justify this, we have done concentration analysis, and we illustrated the results with the Lorenz curve and measured the extent of the concentration with Gini-index.

During our analysis, we filtered those companies from the pattern, of whom the operating revenue for the year 2004 and 2013 was not higher than ten thousand euros. After the filtration remained 2908 companies, these companies have been clustered based on their accounting system: whether they prepare the financial statements on IFRS or local accounting basis.

In order to assess the impact of different accounting treatments, we analyzed the income statement and the notes of published consolidated financial statements of companies with different residence countries. The notes are an obligatory part of the financial statements; we extracted further information from them to reveal the content of gaming revenue and in connection with it, in which part of the income statement is the gaming tax recognized.

We examined income statements and notes of large and very large companies from the top 10 countries to reveal the form and content of disclosures of revenue and gaming tax.

\section{REVENUE OF THE GAMBLING INDUSTRY IN EUROPE}

Examining the data on operating revenue, small companies represent less than 5\% of the annual operating revenue, while the typical proportion of the large and very large companies is approximately $90 \%$. It suggests that the gambling market is highly concentrated.

Illustrating the data in 2004 and 2013 on a Lorenz curve, we can see that the curve is almost the same in the two years: both of them show a very high concentration.

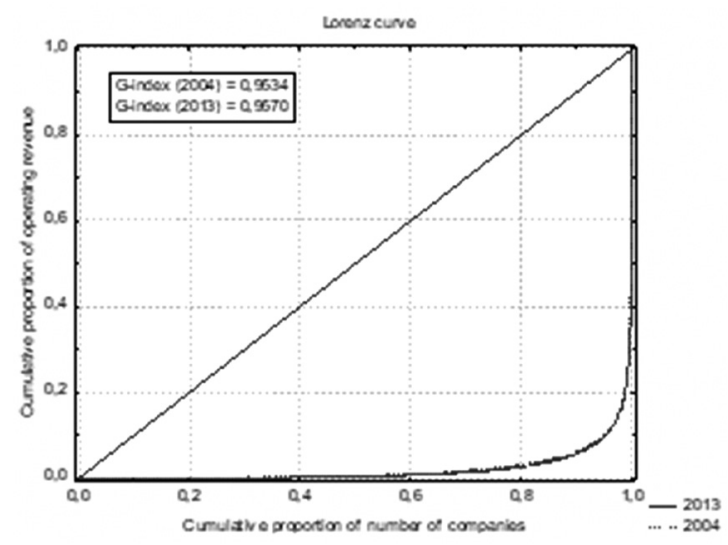

Figure 1. Lorenz curve 2013 and 2004

Source: Amadeus database, own processing 
Gini indexes exceed the value of 0.95 , which indicates an exceptionally high concentration. In this context, nothing has changed over the ten years: concentration has been the same year by year. For example, in 2012, nearly 50\% of the operating revenue was represented by 11 companies.

The highest operating revenue through the period analyzed is generated in Western Europe, followed by the Northern region, and finally in the Central region. According to activity, analyzing the data in 2013, we found that $44 \%$ of the total revenue was represented by only 13 companies of $\mathrm{m}^{5}$, which is almost as much as the revenue of 129 land-based companies. Filtered by country, the highest operating revenue is generated in the United Kingdom, exceeding all other countries in the period examined. Almost 50\% of the total revenue in 2013 was earned by those British companies that rank first, including a mixed company, whose revenue represents $80 \%$ of British revenues.

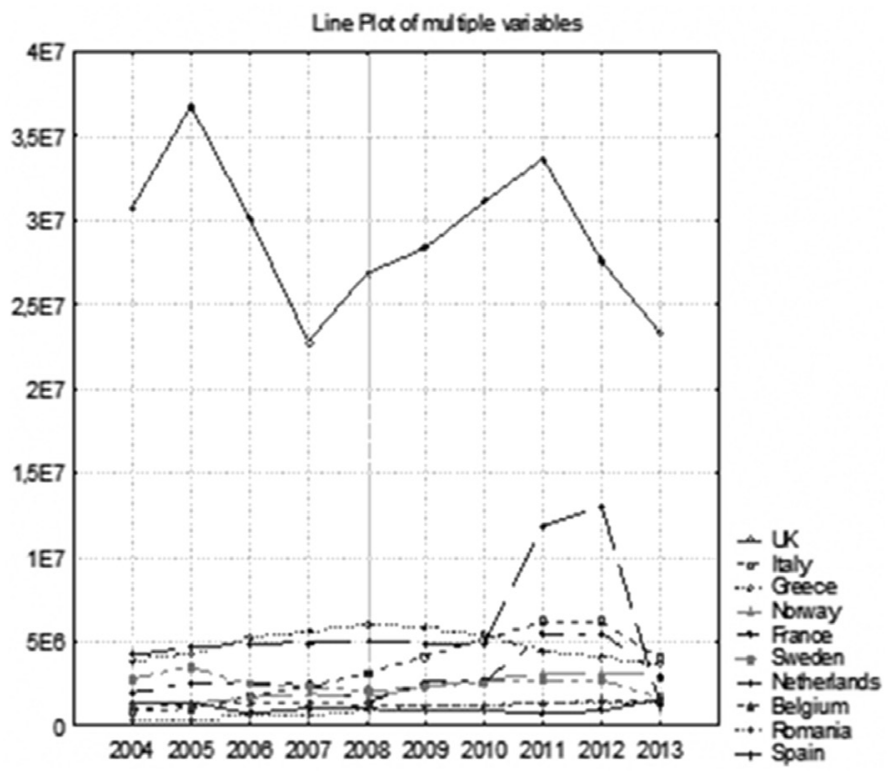

Figure 2. Top 10 countries based on operating revenue between 2004 and 2013 (in TEUR)

Source: Amadeus database, own processing

In several European countries, tourism is one of the most important drivers of economic growth, such as in Croatia (Skuflic et al., 2013), Slovenia, Spain, etc. (European Casino Association, 2015). From the sample in 2013, we can see that among the ten countries that have the highest gambling revenue (See Figure 2. Top 10 countries based on operating revenue between 2004 and 2013), six countries are listed in the top 10 tourist destinations (Eurostat, 2015).

In the concentration analysis, we have already highlighted that the total revenue is defined by the revenue of only a few companies. Thus, the revenue of the sector depends on the revenue of these companies. Following the economic crisis, in some countries, we experienced an increase, but it was due to the increase in large companies. So as to examine the revenue of the vast majority of the companies (See Figure3. Total industrial operating revenue trimmed mean 20042013), by calculating trimmed mean (,middle' 90\%) we eliminated the data of the dominant companies. Since 2007 the vast majority of the companies in the sector have been characterized by decreasing revenue.

In the years examined, the European gambling companies generated an average of 1 million euros in net revenue. We found some European countries where the industry shows losses in

$5 \quad$ Mixed type companies operate both land-based and online gambling activities. 
certain years. In the years examined, generally, one-third of the European companies reported losses, of which one half operated at a loss, while in the other half, the loss was caused by the financial activities of the companies.

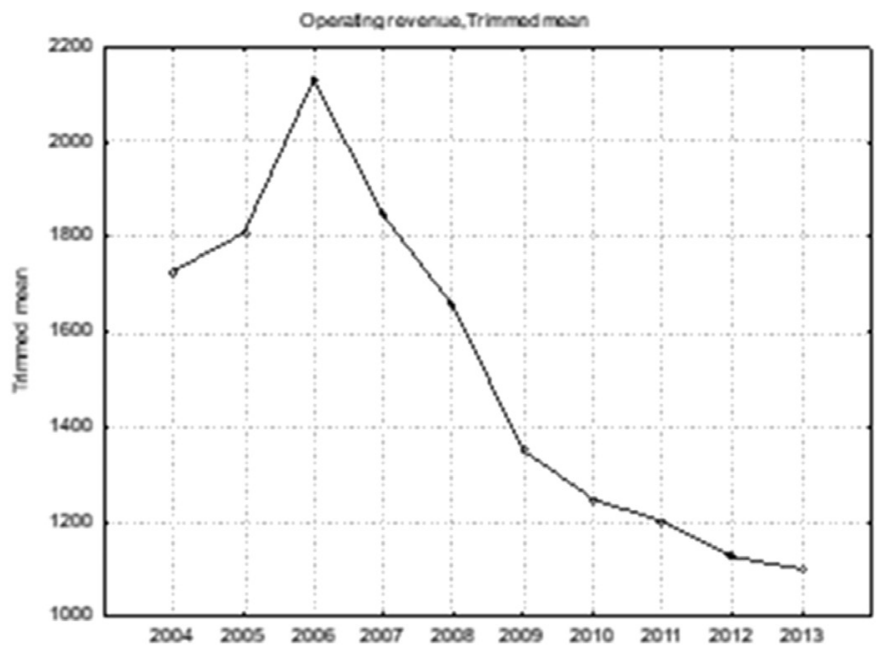

Figure 3. Total industrial operating revenue trimmed mean 2004-2013 (in TEUR)

Source: Amadeus database, own processing

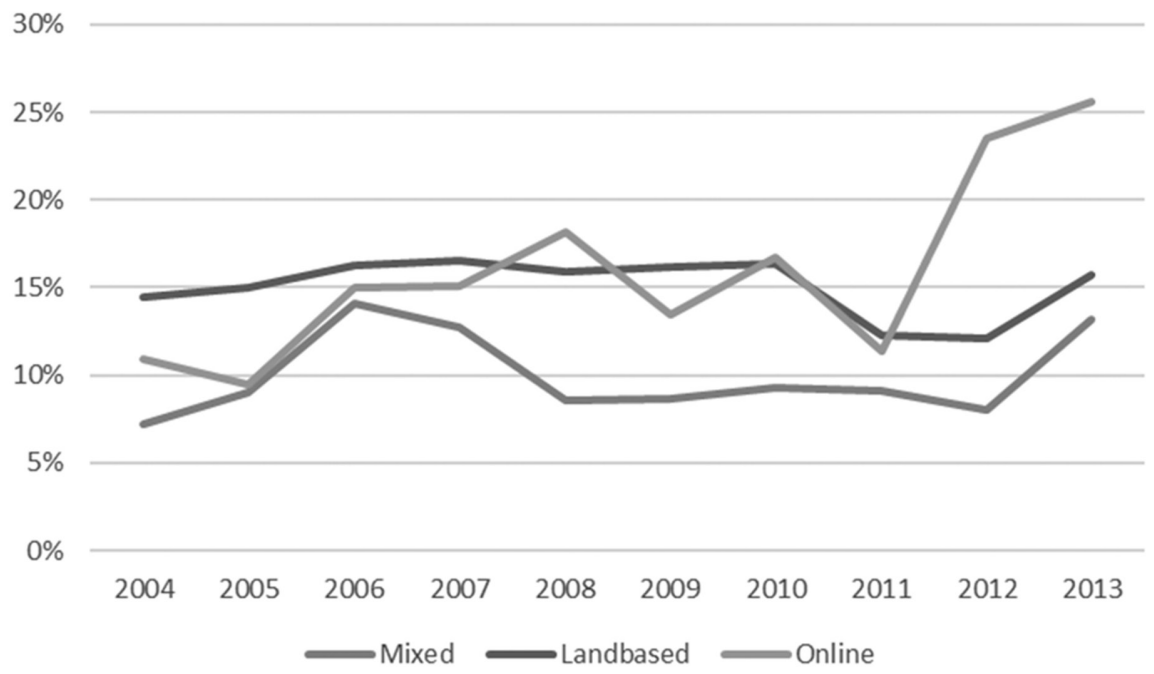

Figure 4. Profit or Loss on Operating revenue

Source: Amadeus database, own processing

The proportions of profit on the operating revenue show that the activity is profitable. The revenues of a company are the main indicators of the entity's financial performance, position, or future prospects for current and potential investors, creditors, and other financial statement users. Therefore, the content of revenue is significant to understand and compare financial statements.

\section{REVENUE AND GAMING TAX RECOGNITION}

The presentation of the gambling revenue in the financial statements highly depends on the definition and presentation of the gambling tax base (see Appendix). The specific features in the gaming and gaming-related activities enable that revenues can be recognized and presented in the financial statements of gambling entities differently. The sales revenue can include the gross 
wager (the total amount of bets) and the revenues from gaming-related activities. If companies present only the gross wager as revenue, the gaming wins are presented as an expense. This form of revenue recognition exists only in domestic accounting systems. IFRS standards do not allow those items that belong to third parties are presented as revenue. We found gambling companies, for example, in Germany or Hungary, that present the gross wager as revenue in their income statement.

The gross gaming revenue is the difference between the amounts received and the amounts paid back to the players as gaming wins. If companies present the gross gaming revenue as revenue in the financial statements, gaming wins are not expensed but deducted from the revenue. This accounting treatment appears both in IFRS financial statements and in financial statements prepared on a domestic regulation basis.

If companies present net gaming revenue in their financial statements, the presented revenue is not only by the wins lower, but it is also adjusted by other items, like incentives, changes in accrued jackpots, or gaming tax.

In Europe, gaming taxes are generally levied progressively by ranges based on gross gaming revenue expressed by percentage, except Hungary and Poland, where we can find a fixed percentage (European Casino Association, 2015; University of Nevada Center of Gaming Research, 2015). We found countries such as Lithuania and the Republic of Estonia, where there are fixed taxes.

Concerning the form of presentation of revenue and gaming tax, empirical results show notable differences in the European domestic and IFRS statements.

Some of the companies recognize gambling tax as an expense, while other companies deduct it from their revenue. If the gambling tax is interpreted as a sales tax, the tax should be deducted from the amount of the revenue. The deduction of the revenue is applied in companies from Austria, France, Italy, and Greece. Our empirical results show that recognition of the gambling tax as an expense is applied in: UK, Spain, Switzerland, the Republic of Estonia and Hungary, although the ways of recognition are not uniform: in UK and Switzerland gambling tax is part of the cost of sales, in the Republic of Estonia, Spain and Hungary it is recognized as a separate operating expense.

Depending on the applied accounting treatment, if the gambling tax is recognized as an expense, the presented revenue is higher by the amount of the gambling tax in the financial statements. Different revenue recognition results in severe difficulties in the analysis. It is considered that the different accounting practices may distort the positions of the countries (see Figure 2) and companies significantly, thus this hierarchy may not be considered reliable for determining comparability or turnover-based market share.

Besides market share, the different accounting practices leave a question mark regarding the reliability of further comparisons, according to several other key indicators as well.

To serve as an example, we examined the consolidated data and revenue indicators of a French, a British, and a Hungarian company with similar gross gambling revenues (GGR). We chose three companies from among the largest ones, with different accounting treatment for revenue and gambling tax recognition. In the income statement of the French company, the winnings and the 
gambling tax are deducted from the sales revenue. The British company presents the gross gaming revenue, while the gambling tax is expensed in the cost of sales. Hungarian firms recognize the sales revenue by calculating the winnings and gambling tax in the other operating expenses.

Because of the lower tax of the British company, we found less significant differences for them than for the other two. For the high-taxed French company, the key performance indicators duplicate. For Hungary, the table contains three columns, because the indicators show notable differences from the indicators calculated by GGR and netted GGR. It is because the indicators are revenue-based.

Table 1. Presentation of gambling revenue and gambling tax in financial statements of European gambling companies in the year 2013

\begin{tabular}{|c|c|c|c|c|c|c|}
\hline $\begin{array}{l}\text { Residence } \\
\text { country }\end{array}$ & $\begin{array}{c}\text { Accounting } \\
\text { basis }\end{array}$ & $\begin{array}{c}\text { Content of } \\
\text { the presented } \\
\text { revenue }\end{array}$ & $\begin{array}{l}\text { Presentation } \\
\text { of Winnings }\end{array}$ & $\begin{array}{c}\text { Presentation } \\
\text { of gambling } \\
\text { taxes }\end{array}$ & $\begin{array}{c}\text { Gambling } \\
\text { tax / Sales } \\
\text { revenue }\end{array}$ & $\begin{array}{l}\text { Gambling } \\
\operatorname{tax} / \text { GGR }\end{array}$ \\
\hline AUSTRIA & IFRS & $\begin{array}{l}\text { GGR, } \\
\text { NGR }\end{array}$ & $\begin{array}{c}\text { Separate de- } \\
\text { duction line in } \\
\text { revenues }\end{array}$ & \begin{tabular}{|c|} 
Separate de- \\
duction line in \\
revenues \\
\end{tabular} & $15,52 \%$ & $46,77 \%$ \\
\hline $\begin{array}{l}\text { CZECH RE- } \\
\text { PUBLIC }\end{array}$ & IFRS & GGR & $\begin{array}{c}\text { Separate de- } \\
\text { duction line in } \\
\text { revenues }\end{array}$ & $\begin{array}{c}\text { A separate } \\
\text { line in Cost of } \\
\text { sales }\end{array}$ & $19,64 \%$ & $21,04 \%$ \\
\hline ESTONIA & IFRS & GGR & $\begin{array}{c}\text { Netted from } \\
\text { revenues }\end{array}$ & $\begin{array}{l}\text { Other operat- } \\
\text { ing expense* } \\
\end{array}$ & n.a & $23,54 \%$ \\
\hline FRANCE & IFRS & $\begin{array}{l}\text { GGR, } \\
\text { NGR }\end{array}$ & $\begin{array}{l}\text { Netted from } \\
\text { revenues }\end{array}$ & $\begin{array}{l}\text { Separate de- } \\
\text { duction line in } \\
\text { revenues }\end{array}$ & n.a & $50,20 \%$ \\
\hline GERMANY & DAS & Sales revenue & $\begin{array}{c}\text { in cost of } \\
\text { Sales }\end{array}$ & \begin{tabular}{|c|}
$\begin{array}{c}\text { In cost of } \\
\text { sales }\end{array}$ \\
\end{tabular} & n.a & $28,65 \%$ \\
\hline GREECE & IFRS & $\begin{array}{c}\text { Sales revenue } \\
\text { GGR } \\
\text { NGR }\end{array}$ & $\begin{array}{c}\text { Separate de- } \\
\text { duction line in } \\
\text { revenues }\end{array}$ & $\begin{array}{c}\text { Separate de- } \\
\text { duction line in } \\
\text { revenues }\end{array}$ & $9,31 \%$ & $28,31 \%$ \\
\hline HUNGARY & DAS & Sales revenue & $\begin{array}{l}\text { in other oper- } \\
\text { ating expense }\end{array}$ & $\begin{array}{l}\text { In other oper- } \\
\text { ating expense }\end{array}$ & $14,52 \%$ & $36,43 \%$ \\
\hline ITALY & IFRS & NGR & $\begin{array}{c}\text { Netted from } \\
\text { revenue }\end{array}$ & $\begin{array}{c}\text { Netted from } \\
\text { revenue }\end{array}$ & n.a & n.a \\
\hline NORWAY & DAS & Sales revenue & $\begin{array}{c}\text { A separate } \\
\text { line in operat- } \\
\text { ing expenses }\end{array}$ & $\begin{array}{l}\text { No gaming } \\
\operatorname{tax}\end{array}$ & - & - \\
\hline SLOVAKIA & IFRS & GGR & $\begin{array}{l}\text { Separate de- } \\
\text { duction line in } \\
\text { revenues }\end{array}$ & \begin{tabular}{|c|} 
A separate \\
line in operat- \\
ing expense \\
\end{tabular} & n.a & $11,15 \%$ \\
\hline SPAIN & IFRS & GGR & $\begin{array}{l}\text { Netted from } \\
\text { operating rev- } \\
\text { enue }\end{array}$ & $\begin{array}{c}\text { A separate } \\
\text { line in operat- } \\
\text { ing expenses }\end{array}$ & n.a & $50,21 \%$ \\
\hline SWEDEN & IFRS & GGR & $\begin{array}{c}\text { Netted from } \\
\text { revenues }\end{array}$ & $\begin{array}{c}\text { No gaming } \\
\text { tax }\end{array}$ & - & - \\
\hline UK & IFRS & GGR & $\begin{array}{c}\text { Netted from } \\
\text { revenues }\end{array}$ & $\begin{array}{c}\text { In cost of } \\
\text { sales }\end{array}$ & n.a & $15,00 \%$ \\
\hline
\end{tabular}

DAS: Domestic Accounting Standards

IFRS: International Financial Reporting standards

Sales revenue: Revenue without any deductions

GGR: Sales revenue - Winnings

NGR: GGR - Gambling tax

* Netted in GGR: when tax paid on the wager and in Other operating expense: when tax paid on GGR 
Table 2. Performance indicators of selected companies

\begin{tabular}{|l|c|c|c|c|c|c|c|}
\hline & \multicolumn{2}{|c|}{ English Company } & \multicolumn{2}{|c|}{ French Company } & \multicolumn{3}{c|}{ Hungarian Company } \\
\hline & $\begin{array}{c}\text { Based on } \\
\text { GGR }\end{array}$ & $\begin{array}{c}\text { Based on } \\
\text { NGR }\end{array}$ & $\begin{array}{c}\text { Based on } \\
\text { GGR }\end{array}$ & $\begin{array}{c}\text { Based on } \\
\text { NGR* }\end{array}$ & $\begin{array}{c}\text { Based on } \\
\text { GGR }\end{array}$ & $\begin{array}{c}\text { Based on } \\
\text { NGR }\end{array}$ & $\begin{array}{c}\text { Based on } \\
\text { Sales }\end{array}$ \\
\hline EBITDA margin & 0.37 & 0.4 & 0.11 & 0.22 & 0.21 & 0.33 & 0.08 \\
\hline Operating margin & 0.32 & 0.34 & 0.04 & 0.08 & 0.19 & 0.29 & 0.07 \\
\hline Net margin & 0.3 & 0.32 & 0.01 & 0.02 & 0.15 & 0.24 & 0.06 \\
\hline Effective tax rate & $8 \%$ & & $50 \%$ & & $35 \%$ & & \\
\hline
\end{tabular}

Data source: Annual reports of companies

\section{CONCLUSION}

The operation of the gambling industry differs significantly from other services. The specification in the industry has become more important in both market and financial analyses and the accounting system.

The results indicate that in Europe, the gambling market is highly concentrated. Only a few companies generate a substantial part of the revenue of this sector.

The popularity of the land-based activity also derives from its positive effect on tourism. It has a positive effect on the local economy ( $\mathrm{Li}$ et al., 2010), such as has been experienced in Korea and Singapore (ECA’s European Casino, 2013; Shin \& Koo, 2011).

Gambling revenues are recognized as a total amount wagered or as the difference between gaming wins and losses or as gaming revenues netted by the gambling tax. In several European countries, the gambling tax is determined based on gross gaming revenue. The tax rate may be influenced by not only the amount of revenue, but the nature of the activity as well, and may differ by country. Gu \& Li (2009) explained the different tax rates adopted by gaming economies with their different market conditions such as supply market and market size.

As for European IFRS statements, empirical results show differences in the accounting of gambling tax. The gambling tax was recognized either as a revenue reduction item or as an expense, depending on the accounting practice in the country. These different recognition methods for gambling revenues and expenses made significant differences in certain rows of the statements of comprehensive income.

For the users of financial statements, revenues of a company are indicators of the financial performance and position or future prospects of an entity. The different accounting methods are important not only for the determination of the market share but for comparison with other countries' companies as well. It may be stated that in the European gambling industry, revenue-based key indicators were not comparable in the examined period.

This study calls attention to this specific service sector and to the impact of applying different accounting treatments when preparing financial statements on the different underlying assumptions. The presentation differences shadow the clearness of information used by decision-makers. If specific accounting guidance for the gambling sector existed, it would enhance the transparency and comparability of financial statements. In its absence, the quantification of an accounting value may vary from nation to nation, thus laying additional burdens on companies when preparing consolidated reports, and sometimes distorting rational decision-making of the 
users relating to financial statements. The country- and company-specific differences in revenue recognition result in the lack of uniform measurement basis of the revenue in the gambling industry and hamper the reliability of revenue-based indicators.

\section{REFERENCES}

Ahmed, A. S., Neel, M., \& Wang, D. (2013). Does mandatory adoption of IFRS improve accounting quality? Preliminary evidence. Contemporary Accounting Research, 30(4), 1344-1372.

Albu, C. N., Albu, N., Pali-Pista, S. F., Gîrbină, M. M., Selimoglu, S. K., Kovács, D. M., \& Strouhal, J. (2013). Implementation of IFRS for SMEs in Emerging Economies: Stakeholder Perceptions in the Czech Republic, Hungary, Romania and Turkey. Journal of International Financial Management \& Accounting, 24(2), 140-175. doi: 10.1111/jifm.12008

Alvarez-Martinez, M. T., \& Lahr, M. L. (2016). Gaming, States, and Tax Revenues - the Tortoise or the Hare: A CGE Comparative Assessment of Casino Resorts and Games-Only Casinos. Growth and Change, 47(2), 236-258.

Andor, G. \& Rózsa, I. (2013). Should Codification emerge in IFRS? Does form of regulation matter? Acta Polytechnica Hungarica, 10(8), 187-204.

AICPA (2017) Audit and Accounting Guide. Gaming. American Institute of Certified Public Accountants, 2017

Barth, M. E., Landsman, W. R., \& Lang, M. H. (2008). International accounting standards and accounting quality. Journal of accounting research, 46(3), 467-498.

Beco, E. (1996). Prevalence surveys of problem and pathological gambling in Europe: The cases of Germany, Holland and Spain. Journal of Gambling Studies, 12(2), 179-192.

Benar, H., \& Jenkins, G. P. (2008). The economics of casino taxation. Applied Economics, 40(1), 63-73.

Brenner, R. \& Brenner, G. A. (1990). Gambling and Speculation: A Theory, a History, and a Future of Some Humans. Cambridge University Press.

Clotfelter, C. T. (2005): Gambling taxes. In: Cnossen, S. (Ed.). Theory and practice of excise taxation: smoking, drinking, gambling, polluting, and driving. Oxford University Press.

Demetrovics, Z., Urbán, R., Nagygyörgy, K., Farkas, J., Zilahy, D., Mervó, B., Reindl, A., Ágoston, C., Kertész, A. \& Harmath, A. (2011). Why do you play? The development of the Motives for Online Gaming Questionnaire (MOGQ). Behavior Research Methods, 43(3), 814-825. doi: 10.3758/s13428-011-0091-y

Ding, Y., Hope, O. K., Jeanjean, T., \& Stolowy, H. (2007). Differences between domestic accounting standards and IAS: Measurement, determinants and implications. Journal of accounting and public policy, 26(1), 1-38.

Eadington, W. R. (2003). The spread of casinos and their role in tourism development. In Tourism Development (pp. 135-150). Routledge.

Eadington, W. R. (2011). After the great recession: The future of casino gaming in America and Europe. Economic Affairs, 31(1), 27-33.

European Casino Association. (2015). ECA's European Casino Industry Report 2013. Retrieved from http://www.europeancasinoassociation.org/151.0.html

Eurostat. (2015) Top 10 tourism destinations - nights spent at tourist accommodation establishments, 2013. Retrieved from http://ec.europa.eu/eurostat/statistics-explained/index. php/File:Top_10_tourism_destinations_\%E2\%80\%94_nights_spent_at_tourist_accommodation_establishments,_2013_\%28million_nights_spent_in_the_country_by_non-residents\%29_YB15.png 
Finger, R. (2013, Jun 30). Online Gambling: A Pastime Whose Time Has Come. Forbes. Retrieved from http://www.forbes.com/sites/richardfinger/2013/06/30/online-gambling-apastime-whose-time-has-come/

Forberger, S., \& Bühringer, G. (2014). Government Regulations of the Gambling Market: Between Nanny State and Laissez Faire? Reframing addictions: policies, processes and pressures, 58.

Gandullia, L., \& Leporatti, L. (2019). Distributional effects of gambling taxes: empirical evidence from Italy. The Journal of Economic Inequality, 17(4), 565-590.

Greenlees, E. M. (2008). Casino Accounting and Financial Management. University of Nevada Press.

$\mathrm{Gu}$, Z. (2002). Performance gaps between US and European casinos: A comparative study. UNLV Gaming Research \& Review Journal, 6(2), 53.

Gu, Z., \& Gao, J. Z. (2006). Financial competitiveness of Macau in comparison with other gaming destinations. UNLV Gaming Research \& Review Journal, 10(2), 1.

$\mathrm{Gu}, \mathrm{X} .$, \& Li, G. (2009). Why do various gaming markets adopt different tax rates, Journal of Gambling Business and Economics, 3(1), 65-88.

Hoogendoorn, M. (2006). International accounting regulation and IFRS implementation in Europe and beyond-experiences with first-time adoption in Europe. Accounting in Europe, $3(1), 23-26$.

Karai, E., Nagy, J., Erdei, J. \& Lakatos, M. (2018). Are revenues comparable? The case of European Gambling Companies. In ITEMA 2018: Recent Advances in Information Technology, Tourism, Economics, Management and Agriculture. Proceedings of Second Scientific Conference, November 8, 2018, Graz University of Technology, (Graz, Austria). - Belgrade: Association of Economists and Managers of the Balkans, 2018. ISBN 978-8680194-13-4, 438-445.

Kingma, S. (2004). Gambling and the risk society: The liberalisation and legitimation crisis of gambling in the Netherlands. International Gambling Studies, 4(1), 47-67.

Kingma, S. F. (2008). The liberalization and (re) regulation of Dutch gambling markets: National consequences of the changing European context. Regulation \& Governance, 2(4), 445-458.

Körmendi, A. (2011). Cognitive distortions and personality traits in gambling players. (In Hungarian: Kognitív torzitások és személyiségvonások vizsgálata szerencsejátékosoknál). University of Debrecen.

Kun, B., Balázs, H., Arnold, P., Paksi, B., \& Demetrovics, Z. (2012). Gambling in western and eastern Europe: The example of Hungary. Journal of Gambling Studies, 28(1), 27-46.

Langmead, J. M., \& Soroosh, J. (2009). International financial reporting standards: The road ahead. The CPA Journal, 79(3), 16.

Li, G., Gu, X., \& Siu, R. C. S. (2010). The impacts of gaming expansion on economic growth: A theoretical reconsideration. Journal of Gambling Studies, 26(2), 269-285.

Meich, B. F. (2008). The power to destroy: The psychology of gaming taxation. Gaming Law Review and Economics, 12(5), 458-465.

Meyer, G., Hayer, T., \& Griffiths, M. (2009). Problem gambling in Europe. Springer.

Nikkinen, J., Egerer, M., \& Marionneau, V. (2018). Introduction: Gambling regulations and the use of gambling revenues in European welfare states. In Gambling Policies in European Welfare States (pp. 1-14). Palgrave Macmillan, Cham.

Paton, D., Siegel, D. S., \& Vaughan Williams, L. (2002). A policy response to the e-commerce revolution: The case of betting taxation in the UK. The Economic Journal, 112(480). 
Philander, K. S. (2013). A normative analysis of gambling tax policy. UNLV Gaming Research \& Review Journal, 17(2), 2.

Philander, K. S., Bernhard, B. J., Wimmer, B. S., Singh, A. K., \& Eadington, W. R. (2015). US casino revenue taxes and short-run labour outcomes. Journal of Policy Modeling, 37(1), 35-46.

Planzer, S., Gray, H. M., \& Shaffer, H. J. (2014). Associations between national gambling policies and disordered gambling prevalence rates within Europe. International Journal of Law and Psychiatry, 37(2), 217-229.

Rezaee, Z., Smith, L. M., \& Szendi, J. Z. (2010). Convergence in accounting standards: Insights from academicians and practitioners. Advances in Accounting, 26(1), 142-154.

Rózsa, I. (2013). Difficulties of applying IFRS in continental Europe from the perspective of codification. Periodica Polytechnica, 21(2), 91-97. Retrieved from http://www.pp.bme.hu/ so/article/view/7088/6198

Shin, D-H. \& Koo, B-K. (2011). Response Strategy of Tourist Market through Analysis of the Gambling Industry. Korean Journal of Tourism Research, Vol.26. No.3, 211-223.

Siu, R. C. S. (2007). Is casino gaming a productive sector? A conceptual and cross-jurisdiction analysis. Journal of Gambling Business and Economics, 1(2), 129-146.

Smith, J. (2000). Gambling taxation: Public equity in the gambling business. Australian Economic Review, 33(2), 120-144.

Thompson, W. N. (1998). Casinos de juegos del mundo: A survey of world gambling. The ANNALS of the American Academy of Political and Social Science, 556(1), 11-21.

University of Nevada Center of Gaming Research (2015). Macau Gaming Summary. Retrieved from http://gaming.unlv.edu/abstract/macau.html.

Wagenhofer, A. (2014). The role of revenue recognition in performance reporting. Accounting and Business Research, 44(4), 349-379.

Walker, D. M., \& Sobel, R. S. (2016). Social and economic impacts of gambling. Current Addiction Reports, 3(3), 293-298. 